\title{
Apparent Nucleation and Freezing in Various Parts of Young Citrus Trees during Controlled Freezes
}

\author{
George Yelenosky \\ U.S. Department of Agriculture, Agricultural Research Service, \\ Horticultural Research Laboratory, 2120 Camden Road, Orlando, \\ FL 32803
}

Additional index words. sequential freezing, ice propagation, exotherms, freeze injury, Citrus sinensis

\begin{abstract}
One- to 4-year-old sweet orange trees, Citrus sinensis (L.) Osbeck CV. Valencia on rough lemon ( $C$. jambhiri Lush.) rootstock, were used in a series of tests on the depth and stability of supercooling in various parts of greenhouse-grown trees held in pots during controlled freezes. Thermocouples were attached to flowers, fruit, leaves, and wood. Supercooling levels were inconsistent, ranging from - 3C to - 7C. Nucleation was spontaneous and well defined by sharp exotherms. Rapid progression of crystallization $\left(\approx 60 \mathrm{~cm} \cdot \mathrm{min}^{-1}\right)$ indicated no major obstacles to ice propagation throughout the tree above soil level. The site of initial freezing was variable, with a tendency for trees to freeze from the base of the stem toward the top. The location of tissue damage did not necessarily correspond to the location of initial freeze event. Freezing in the wood often preceded freezing of flowers.
\end{abstract}

The relatively short duration and infrequency of severe freezes in subtropical climates (Quamme et al., 1982; Yelenosky, 1985) make freeze avoidance through supercooling a potential mechanism for cold protection of evergreen Citrus. There is no apparent unique ice-nucleating temperature per se for any one citrus cultivar, and freezing curves may deviate from ideal freezing behavior (Anderson et al., 1983). Studies are limited, but available data suggest that the nucleation event is largely unpredictable and the velocity of ice propagation tends to be a temperature-dependent process in citrus seedlings (Yelenosky and Horanic, 1969). It is unclear what freezing catalysts are involved in field citrus trees. The role of icenucleating active bacteria does not appear sufficiently important to warrant extensive control in the field (Proebsting and Gross, 1988). Also, anatomical and age features are variable (Lincheng et al., 1984; Salazar, 1966), and specific sites of initial nucleation

Received for publication 30 July 1990. The cost of publishing this paper was defrayed in part by the payment of page charges. Under postal regulations, this paper therefore must be hereby marked advertisement solely to indicate this fact. in whole plants are speculative at best (Kaku, 1975). The objective of this study was to determine the characteristics of apparent nucleation for various tissues and organs of young citrus trees in a controlled freeze regime.

Single 'Valencia' trees propagated from state-registered budwood on sour orange rootstock seedlings of open-pollinated seed from a single source tree were grown in 15liter plastic pots containing Pro-Mix [shredded sphagnum peat with equal parts of vermiculite and perlite and macro- and micronutrient elements added (Premier Brands, New Rochelle, N. Y.)]. Single-stem trees were maintained in a $50 \%$ shaded greenhouse under natural-day conditions. Air temperatures in the greenhouse ranged from $32 \mathrm{C}$ during the day to a $15 \mathrm{C}$ minimum at night. Maximum photosynthetic photon flux (PPF) was $1000 \mu \mathrm{mol} \cdot \mathrm{s}^{-1} \cdot \mathrm{m}^{-2}$ at the top of the trees and relative humidity ranged from a low of $35 \%$ during the day to $98 \%$ at night. Trees were watered every 2 days and fertilized monthly with a solution of $12 \mathrm{~N}-2.6 \mathrm{P}-$ $5 \mathrm{~K}$ liquid that contained micronutrients. Test trees ranged in height from 100 to $130 \mathrm{~cm}$, and 0.8 to $2.2 \mathrm{~cm}$ in stem diameter, $10 \mathrm{~cm}$ above the bud union.
Trees were frozen in a walk-in, temperature-controlled room without light and 50\% $\pm 5 \% \mathrm{RH}$. Trees were tested in matched pairs to determine the effect of defoliation on apparent nucleation in the stem, or trees were individually tested to determine the sequence of freezing in various parts, the rate of ice propagation, and the association of freeze kill with site of apparent nucleation. All trees were watered the night before tests and temperature was equilibrated for $2 \mathrm{~h}$ at $4 \mathrm{C}$ before the start of freezing regimes in which temperature was decreased $5 \mathrm{C} / \mathrm{h}$ for varying periods. In some tests, leaves were removed from trees to eliminate leaves as a

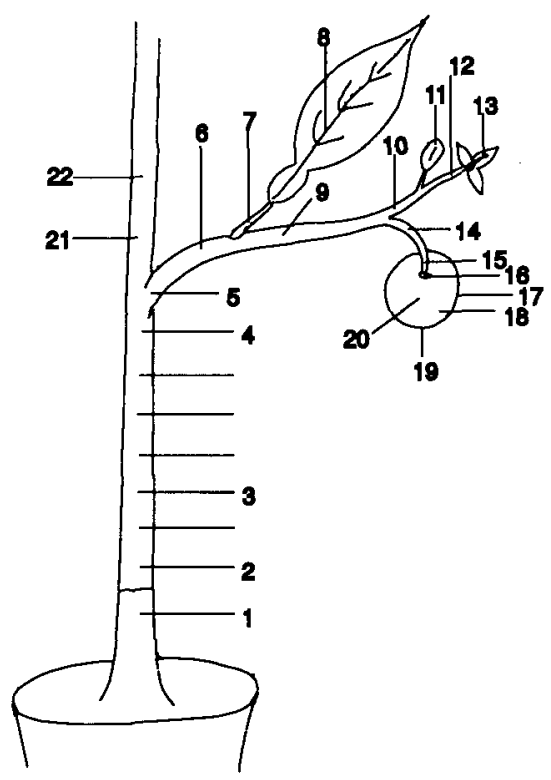

Fig. 1. Relative placement of thermocouples spaced at known intervals for monitoring the initial freezing of a young citrus tree during a controlled freeze regime. Sensors were sequentially aligned respective to each other leading into and exiting from different tree parts. Sensors 1 to $6,9,10,12,14,15,21$, and 22 represent placement on wood surfaces, 7 is leaf petiole, 8 is midvein, 11 is inserted into a closed citrus flower underneath petal cover, 13 is inserted through the stigma into the style of an open flower, 16 is surface-attached to the fruit at the stem end and 18 at the blossom end, 17 is inserted in the albedo next to the vesicles, 19 is inserted into the fruit center through the center pulp core, and 20 is attached to the fruit surface between sensors 16 and $18,90^{\circ}$ from sensor 19. All parts of the tree without sensors were cut off just before freeze test and cut surfaces were covered lightly with lanolin. 
Table 1. Extent of supercooling in the main stem of pairs (sets) of unhardened 1-year-old 'Valencia' trees with and without leaves during a controlled freeze.

\begin{tabular}{|c|c|c|c|c|c|}
\hline \multirow{2}{*}{$\begin{array}{l}\mathrm{Set}^{y} \\
\text { (no.) }\end{array}$} & \multicolumn{2}{|c|}{$\begin{array}{c}\text { Temp }\left({ }^{\circ} \mathrm{C}\right) \text { at start } \\
\text { of freezing }\end{array}$} & \multirow{2}{*}{$\begin{array}{l}\text { Interval } \\
\text { between } \\
\text { freezing } \\
\text { within sets } \\
\text { (rein) }\end{array}$} & \multicolumn{2}{|c|}{$\begin{array}{c}\text { Temp }\left({ }^{\circ} \mathrm{C}\right) \text { at exotherm } \\
\text { plateau }\end{array}$} \\
\hline & Defoliated $^{x}$ & Control & & Defoliated & Control \\
\hline 1 & -5.2 & $-4.7^{*}$ & 4.5 & -4.4 & -4.0 \\
\hline 2 & $-5.2 *$ & -6.2 & 21.4 & -4.2 & -4.4 \\
\hline 3 & -6.2 & $-5.7^{\prime \prime}$ & 5.5 & -4.6 & -4.2 \\
\hline 4 & $-6.0 *$ & -6.2 & 3.0 & -4.7 & -4.2 \\
\hline 5 & $-5.6 *$ & -6.1 & 11.0 & -4.6 & -4.5 \\
\hline 6 & -6.1 & $-5.2 *$ & 9.0 & -4.9 & -4.4 \\
\hline 7 & -6.3 & $-5.6 *$ & 10.5 & -4.8 & -4.6 \\
\hline 8 & -6.6 & $-5.5 *$ & 38.0 & -5.4 & -4.4 \\
\hline 9 & $-5.2 *$ & -7.1 & 61.0 & -4.1 & -5.2 \\
\hline 10 & -7.0 & $-6.4^{*}$ & 8.0 & -5.2 & -4.3 \\
\hline 11 & -8.1 & $-6.2 *$ & 25.0 & -5.8 & -4.4 \\
\hline 12 & $-5.3 *$ & -5.4 & 3.5 & -4.8 & -4.8 \\
\hline 13 & $-5.4 *$ & -5.4 & 1.5 & -4.3 & -4.1 \\
\hline 14 & $-6.6^{*}$ & -7.2 & 10.0 & -5.0 & -5.3 \\
\hline 15 & -6.2 & -6.2 & 1.5 & -4.6 & -4.6 \\
\hline Mean \pm SD & $-6.1 \pm 0.8$ & $-5.9 \pm 0.7$ & $14.2 \pm 16.4$ & $-4.8 \pm 0.4$ & $-4.5 \pm 0.4$ \\
\hline Range & -5.2 to -8.1 & -4.7 to -7.2 & 1.5 to 61 & -4.2 to -5.8 & -4 to -5.2 \\
\hline $\begin{array}{l}\text { Froze first in } \\
\text { matched sets }(\%)^{*}\end{array}$ & 47 & 53 & --- & --- & \\
\hline
\end{tabular}

${ }^{2} 5 \mathrm{C} / \mathrm{h}$ decrease, $50 \% \pm 5 \% \mathrm{RH}$, no light.

'Trees frozen in matched pairs (defoliated-foliated); three sets daily for five successive days.

x Leaves cut off with razor next to main stem immediately before freeze test; cut surface covered with lanolin.

*Froze first in set.

Table 2. Extent of supercooling in the main stem of 2-year-old defoliated 'Valencia' orange trees in bloom on sour orange rootstock during controlled freezes. ${ }^{y}$

\begin{tabular}{|c|c|c|c|c|}
\hline \multirow{3}{*}{$\begin{array}{l}\text { Tree } \\
\text { (no.) }\end{array}$} & \multicolumn{4}{|c|}{ Start of freezing } \\
\hline & \multicolumn{2}{|c|}{ Main stem } & \multicolumn{2}{|c|}{ Open flowers $^{x}$} \\
\hline & ${ }^{\circ} \mathrm{C}$ & Location & ${ }^{\circ} \mathrm{C}$ & Total no. \\
\hline 1 & $-6.6^{*}$ & Lower & -7.0 & 4 \\
\hline 2 & $-7.0 *$ & Top & -7.7 & 3 \\
\hline 3 & $-6.1 *$ & Lower & -6.8 & 4 \\
\hline 4 & $-6.2 *$ & Lower & -7.1 & 4 \\
\hline 5 & $-6.4 *$ & Lower & -6.9 & 4 \\
\hline Mean $\pm \mathrm{SD}$ & $6.5 \pm 0.3$ & & $7.1 \pm 0.3$ & \\
\hline Froze first $(\%)$ & 100 & & 0 & \\
\hline
\end{tabular}

${ }^{2}$ Leaves excised at main stem immediately before freeze test, cut surface covered with lanolin.

${ }^{5} 5 \mathrm{C} / \mathrm{h}$ decrease, $50 \% \pm 5 \% \mathrm{RH}$, no light.

'All flowers removed except those with thermocouple inserted into stigma/style.

*Froze first in set.

Table 3. Relative freezing of flowers and fruit at different stages of development on a 'Valencia' orange tree ${ }^{z}$ during a controlled freeze.

\begin{tabular}{|c|c|c|c|c|c|c|c|}
\hline \multirow[b]{3}{*}{ Flower part } & \multirow{3}{*}{$\begin{array}{c}\text { Order } \\
\text { of } \\
\text { freezing }\end{array}$} & \multirow{3}{*}{$\begin{array}{c}\text { Time } \\
\text { difference } \\
\text { (rein) }\end{array}$} & & & \multicolumn{3}{|c|}{ Exotherm } \\
\hline & & & \multicolumn{2}{|c|}{ Temp $\left({ }^{\circ} \mathrm{C}\right)$} & $\begin{array}{l}\text { Temp } \\
\text { increase }\end{array}$ & \multicolumn{2}{|c|}{ Plateau (rein) } \\
\hline & & & Nucleation & Air & $\left({ }^{\circ} \mathrm{C}\right)$ & Attainment & Duration \\
\hline Ovary (open flower) & 1 & 0 & -4.7 & -4.8 & 1.6 & 2 & 0.5 \\
\hline Closed bud & 1 & 0 & -4.5 & -4.8 & 1.9 & 5 & 1 \\
\hline Open bud & 1 & 0 & -4.6 & -4.8 & 1.2 & 3 & 4 \\
\hline Stigma (open flower & r) 2 & 0.08 & -4.7 & -4.8 & 1.9 & 1.5 & 3 \\
\hline Center-small fruit ${ }^{x}$ & 3 & 3 & -4.2 & -4.9 & 1.3 & 5 & 4 \\
\hline Center-1arger fruit" & 4 & 4 & -2.6 & -5.0 & 0.9 & 10 & 12 \\
\hline Button-largest fruit & 5 & 8 & -3.9 & -5.4 & 0.5 & 6 & 9 \\
\hline Center-largest frui & it" 6 & 9 & -1.7 & -5.5 & 1.0 & 34 & $>21$ \\
\hline Peel-largest fruit & 7 & 19 & -4.0 & -6.0 & 1.2 & 11 & 6 \\
\hline
\end{tabular}

Defoliated to remove leaves as possible sources of nucleation.

${ }^{8} 5 \mathrm{C} / \mathrm{h}$ decrease, $50 \% \pm 5 \% \mathrm{RH}$, no light.

${ }^{x}$ Length $=2 \mathrm{~cm}$, width $=4.2 \mathrm{~cm}$.

"Length $=4.8 \mathrm{~cm}$, width $=4.2 \mathrm{~cm}$.

"Length $=5.6 \mathrm{~cm}$, width $=5.4 \mathrm{~cm}$.

source of nucleation. Leaves were removed with a razor blade at the main stem, and cut surfaces were lightly covered with lanolin.
Three separate differential thermal analysis systems were used in combination to provide a maximum of 34 sensors per freeze test. AH sensors were 36 -gauge $(0.12 \mathrm{~mm}$ diameter), copper-constantan (Type T) thermocouples inserted into open and closed flowers and fruit of the 3- to 4-year-old trees and firmly held against stem and leaf surfaces with plastic clips or 5-mm-wide strips of tape. Thermocouples were also attached at known distances along the main stem, on branches of various sizes and associated leaves, and blossom and stem ends of attached fruit, including mid-diameter peel surface. Placement and number of thermocouples varied depending on the objectives of individual tests (Figs. 1 and 2). Tree parts (branches, leaves, flowers, fruit) that had no sensors were cut off just before freeze tests, and cut surfaces were covered lightly with lanolin. Four thermocouples were connected to digital multimeters ( $1 \mu \mathrm{V} /$ digit resolution) with a rated accuracy of \pm 1 digit and $<2$ sec settling time. The reference junction was an insulated ice bath stable at $0 \pm 0.2 \mathrm{C}$. Digital multimeters were connected to 0- to 100-mV, variable-speed, strip-chart recorders for continuous graphical display of temperature. Fourteen thermocouples were connected to a direct-reading, strip-chart recorder (Digistrip, Kaye Instruments, Bedford, Mass.) with a variable scan from 15 sec to 77 rein, or one channel/see, with a Facit serial-page impact printer. The remaining 16 thermocouples were connected to a thermoelectric thermometer with a RS-232 computer interface (Iso-Thermix, Columbus Instruments, Columbus, Ohio). Rated accuracy is $\pm 0.1 \mathrm{C}$ at $22 \mathrm{C}$ ambient and a resolution of $0.015 \mathrm{C}$. Variable scan was set at $10 \mathrm{sec}$ with number of samples up to 5000 per test. The Iso-Thermix was connected to an IBM-compatible computer for data visualization and analysis.

Trees were thawed for $2 \mathrm{~h}$ by increasing temperature in the freeze room at 2 to $5 \mathrm{C} / \mathrm{h}$, except where noted, to $4 \mathrm{C}$; then trees were returned to the greenhouse and held for 5 weeks of observation of freeze injury development.

Freezing (ice crystallization) was characterized by well-defined exotherms regardless of thermocouple location in $>1000$ placements on trees during controlled freezes. There was no apparent advantage to inserting thermocouples into organs over surface attachment, except for flowers and inside fruit, which were more suited for inserted probes. Latent heat of crystallization often exceeded $1 \mathrm{C}$ at the onset of freezing, and was sufficient to maintain bark temperatures above ambient air for $1 \mathrm{~h}$ and longer, $30 \mathrm{~min}$ for mature leaves, and $15 \mathrm{~min}$ for flowers. Neither sharp, abrupt exotherms (Ashworth et al., 1983) nor multiple exotherms (Quamme et al., 1972; Rajashekar et al., 1982) that are associated with lethal injury to detached tree parts were characteristic of injurious freezing in citrus trees during this study. Flowers and leaves $<1$ week old did not survive $5 \mathrm{sec}$ after the moment of crystallization, based on high discoloration and loss of turgidity within $4 \mathrm{~h}$ after rapid thaw from 5 $\mathrm{sec}$ of crystallization. Thawing frozen citrus tissues from temperatures as low as $-7 \mathrm{C}$ in 


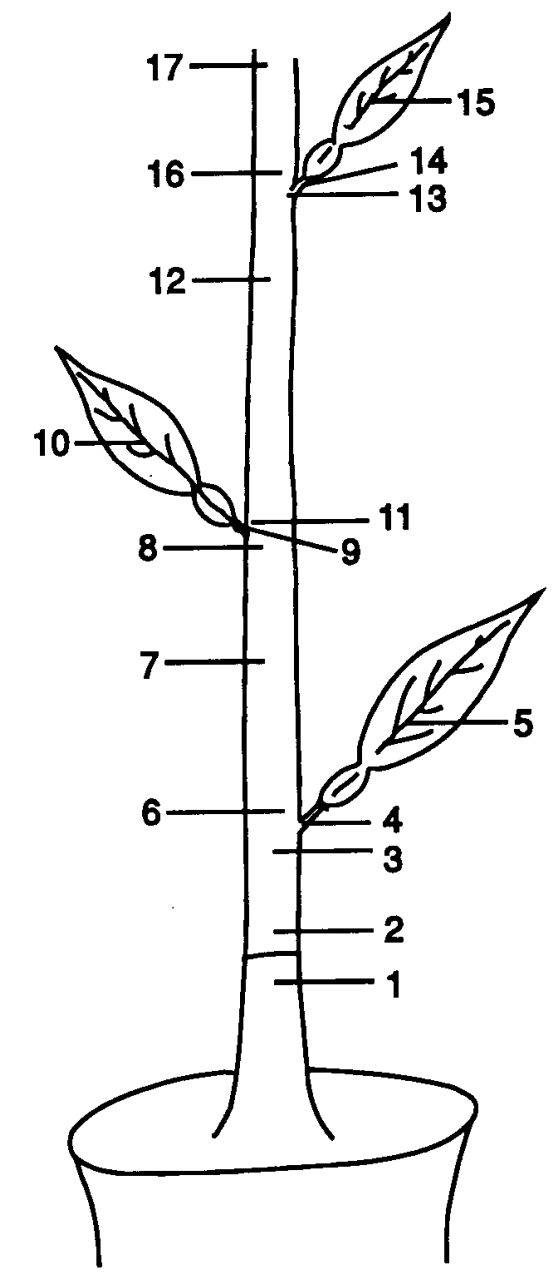

Fig. 2. Relative placement of thermocouples spaced at known intervals for monitoring the vertical progression of ice spread in a young citrus tree during a controlled freezing regime. Trees were grown without lateral branches, and all leaves without sensors were cut off close to the main stem just before freeze test. Cut surfaces were covered lightly with lanolin.

full sunlight does not increase freeze damage over trees thawed slowly, $1 \mathrm{C} / \mathrm{h}$ (unpublished data). This apparent quick kill in flowers was not evident in mature leaves and stem wood. Citrus flowers and immature leaves apparently have no significant ice tolerance relative to their considerable ability to supercool (Yelenosky, 1988). Water-soaking occurred in all frozen leaves within 2 min after freezing, and water-soaking patterns were similar to those previously reported (Young and Peynado, 1967). Water-soaking of stems was most evident in young, green wood and essentially was not visible in older wood. Levels of supercooling were too variable for any opportunity to accurately predict them within $\pm 1 \mathrm{C}$ for any one tree based on immediately completed tests. Velocity of ice propagation, based on timing of nucleation events between thermocouples of known distances, exceeded $60 \mathrm{~cm} \cdot \mathrm{min}^{-1}$. These observations are consistent with the concept of randomness of initial freezing in citrus and the apparent lack of a unique temperature at which nucleation occurs (Franks, 1987). In this study, initial sites of freezing were not nec- essarily sites where freeze kill developed. This lack of correspondence was evident in matching tree injury after 5 weeks of observations with the initial freezing event site known by thermocouple placement marked with black ink.

Whether nucleation occurs first in the leaves with ice propagating into the main stem or vice versa was not fully resolved. Freezemonitoring of unhardened, matched foliated and defoliated trees suggested freezing may occur at random between leaves and wood with no preferred location or critical threshold temperature (Table 1). For all practical purposes, leaves did not significantly influence initial freezing temperatures in the main stem, supercooling levels, or which trees froze first. The lag time of 1.5 to $61 \mathrm{~min}$ between freezing of two trees is considered, long enough to partially account for wide differences in freeze injury to citrus trees between -5 and $-7 \mathrm{C}$ during freezes of short duration (Yelenosky, 1985). In such cases, freeze avoidance through supercooling may be more important than ice tolerance in final freezedamage assessments. Such levels of freeze avoidance are not well established in citriculture, and critical nucleation measurements are largely lacking in field situations. Field-monitored freeze avoidance seemingly is limited to temperatures between -0.6 and - 2.6C for Prunus during natural freezes (Ashworth et al., 1985). This narrow range would be of little significance to citrus during severe freezes at $-7 \mathrm{C}$, but could be important during typical freezes in subtropical climates (Yelenosky, 1985). Similar to Prunus (Proebsting and Gross, 1988), freezing in the wood may have catalyzed freezing in flowers on defoliated 'Valencia' trees in bloom (Table 2). Cooler tissues did not necessarily have a higher probability of freezing first because flowers were as much as $0.9 \mathrm{C}$ colder than the wood. More extensive studies would help to determine if warmer (but below freezing) tree parts freeze before colder tree parts under field situations where large differences in mass and radiation cooling exist.

The earlier freezing of the lower stem implies that this may be a significant site of initial ice nucleation (Table 2). Whether rootstock could be sites for or help promote early freezing was not pursued in this study. The involvement of rootstock in helping to promote early freezing in lower stems would add another consideration for insulator wraps in citrus freeze survival (Yelenosky and Reese, 1979).

The freezing sequence of reproductive tissues supports relatively rapid freezing in citrus with $<5$ min between first freezing noted in flowers and first freezing noted in developing fruit (Table 3). In this instance, colder flower parts froze first and apparent propagation of ice was to warmer fruit. Exotherms were well defined with abrupt, short patterns for flowers and more gradual and longerlasting patterns for internal freezing of fruit that ranged from young fruit, $3.5 \mathrm{~cm}$ middiameter $(0.23-\mathrm{cm}$ peel thickness, $0.60-\mathrm{cm}$ albedo thickness, 0.80 -cm vesicles, and 0.45 - cm pulp center), to older fruit, 9-cm middiameter $(0.19-\mathrm{cm}$ peel thickness, $0.23-\mathrm{cm}$ albedo, 3.6- $\mathrm{cm}$ vesicles, and $1.2-\mathrm{cm}$ pulp core). The peel was the last part of the monitored fruit to freeze, which suggests the possibility of internal fruit freezing before surface nucleation. This internal fruit nucleation and early freezing of the lower stem seemingly are more associated with the concept of intrinsic ice nuclei than external ice nucleation-active agents (Proebsting and Gross, 1988).

The pattern of freezing in this study was a rapid succession of apparent nucleation in all directions from the first point of freezing and favors whole-tree freezing from a single nucleation event with no significant internal barriers to rapid propagation of ice throughout the young trees. Sectioned trees, with alignment maintained and Parafilm (American Natl. Can, Greenwich, Corm. ) in cross cuts between evenly spaced thermocouples, did not show a succession of apparent nucleation. In this instance, sectioned parts froze independently of each other, as much as 15 min between first and last apparent nucleation. The vast possibilities for nucleation sites, micro-climate differences, and rapid succession of nucleation events relative to a limited number of sampling points cast suspicion on how uniform freezing is occurring in the field. The large differences in tree mass, exposure of different tree parts, radiation cooling, and convective heat loss during natural freezes that occur in the orchard may result in multiple nucleation similar to that in peach trees (Ashworth et al., 1985). Whether the nucleation of the whole tree is from a single or multiple source, the apparent randomness of nucleation events, rapid propagation of ice, and nonspecific nucleation sites found in this study suggest more transient than fixed nucleating sites. The apparent internal catalyst that increases the probability of nucleation at a given temperature remains unclear and may be more metabolic than an anatomical fixed feature or a specific contaminant that catalyses ice structure.

\section{Literature Cited}

Anderson, J.A., L.V. Gusta, D. W. Buchanan, and M.J. Burke. 1983. Freezing of water in citrus leaves. J. Amer. Soc. Hort. Sci. 108:397-400.

Ashworth, E.N., J.A. Anderson, G.A. Davis, and G. W. Lightner. 1985. Ice formation in Prunu.s persica under field conditions. J. Amer. Soc. Hort. Sci. 110:322-324.

Ashworth, E.N., D.J. Rowse, and L.A. Billmyer. 1983. The freezing of water in woody tissue of apricot and peach and the relationship to freezing injury. J. Amer. Soc. Hort. Sci. 108:299303.

Franks, F. 1987. Nucleation: a maligned and misunderstood concept. Cryo-Letters 8:53-55.

Kaku, S. 1975. Analysis of freezing temperature distribution in plants. Cryobiology 12:154-159.

Lincheng, J., S. Longhua, H. Shanwen, and X. Deiming. 1984. Ultrastructural adoptive changes in the leaf cells of citrus trees from growing season to hard winter period. Acta Hort. Sinica 11:79-82.

Proebsting, E.L. Jr., and D.C. Gross. 1988. Field evaluations of frost injury to deciduous fruit trees as influenced by ice nucleation-active Pseudo- 
monas syringae. J. Amer. Soc. Hort. Sci. 113:498-506.

Quamme, H. A., R.E.C. Layne, and W.G. Ronaid. 1982. Relationship of supercooling to cold hardiness and the northern distribution of several cultivated and native Prunus species and hybrids. Can. J. Plant Sci. 62:137-148.

Quamme, H., C. Stushnoff, and C.J. Weiser. 1972. The relationship of exotherms to cold injury in apple stem tissues. J. Amer. Soc. Hort. Sci. 97:608-613.
Rajashekar, C., M.N. Westwood, and M.J. Burke, 1982. Deep supercooling and cold hardiness in genus Pyrus. J. Amer. Soc. Hort. Sci. 107:968972 .

Salazar, C.G. 1966. Comparative anatomy of citrus and cold hardiness. J. Agr. Univ. Puerto Rico 50:316-336.

Young, R. and A. Peynado. 1967. Freezing and water soaking in citrus leaves. Proc. Amer. Soc. Hort. Sci. 91:157-162.
Yelenosky, G. 1985. Cold hardiness in citrus. Hort. Rev. 7:201-238

Yelenosky, G. 1988. Capacity of citrus flowers to supercool. HortScience 23:365-367.

Yelenosky, G. and G. Horanic. 1969. Subcooling in wood of citrus seedlings. Cryobiology 5:281283.

Yelenosky, G. and S. Reese. 1979. Self-heating tree wraps in freeze protection. Proc. Fla. State Hort. Soc. 92.25-27. 